\title{
Wine and Non-Dairy Fermented Beverages: A Novel Source of Pro- and Prebiotics
}

\author{
Alice Vilela * ${ }^{*}$, Fernanda Cosme $\mathbb{D}^{\mathbb{D}}$ and António Inês \\ CQ-VR, Chemistry Research Centre, Department of Biology and Environment, School of Life Sciences and \\ Environment, University of Trás-os-Montes and Alto Douro, 5001-801 Vila Real, Portugal; fcosme@utad.pt (F.C.); \\ aines@utad.pt (A.I.) \\ * Correspondence: avimoura@utad.pt; Tel.: +351-259-350-973; Fax: +351-259-350-480
}

Received: 28 October 2020; Accepted: 17 November 2020; Published: 20 November 2020

\begin{abstract}
Probiotics and prebiotics are microbiota-management instruments for improving human health once they may be beneficial for maintaining a healthy community of gut microbiota and bowel function. Probiotic's main target is the gut, via the gastrointestinal tract, although direct application to other body zones such as the vaginal tract, the oral cavity, and skin have been studied. The major source of probiotics is fermented dairy products, however, currently, there is a need for novel and non-dairy probiotics, due to the increasing number of lactose-intolerant persons in the world population, tied with the adverse effect of cholesterol contained in fermented dairy foods as well as the increasing number of strict vegetarians. In this review, we describe gut-derived effects in humans of possible microorganisms isolated from wine, such as Saccharomyces and non-Saccharomyces yeasts and bacteria, and other non-dairy fermented beverages. Those microorganisms can be grown and consumed as recommended probiotics, moreover, wine, and other beverages may also be a source of prebiotics such as polyphenols.
\end{abstract}

Keywords: wine-yeasts; lactic acid bacteria; prebiotics; probiotics; human health

\section{Introduction}

Although people often think of bacteria and other microorganisms as harmful "germs," many are helpful. Some bacteria help digest food, destroy disease-causing cells, or produce vitamins. Many of the microorganisms in probiotic products are the same as or like microorganisms that naturally live in our bodies. Probiotics are part of a larger picture concerning microbes and our body-our microbiome. These microbes are a combination of bacteria, fungi (including yeasts), viruses, and protozoa. Everyone's microbiome is unique, and two people have not the same microbial cells [1].

The most common place linked to beneficial microbes is our gut (mostly the large intestine). The human gut contains over 100-1000 microbial species, more or less than about $10^{11}-10^{12} \mathrm{CFU} / \mathrm{g}$ [2], which modulates the host internal environment and thus, play a major role in host health. Specifically, these organisms play key roles in defense function, good digestion (catabolism and anabolism), and impact brain-gut responses [3]. So, the main acts of the microbiota can be categorised into three groups-metabolic, protective, and trophic functions [4]. Moreover, besides the human gut, several locations in and on our body host good microbes. These locations are in contact with the "outside world" and include the mouth, vagina, urinary tract, skin, and lungs.

Bacterial colonisation of the human gut evolves and transforms over a lifetime. It begins at birth when newborns are exposed to a non-sterile environment [3] which alters the gut microbiome to a predominance of anaerobes within a few weeks of life [5]. It changes over time, depending on a dynamic relationship between the diet, genome, lifestyle, and the composition and number of drugs 
used, such as antibiotics. It can shift according to age, mainly around the time that the immune system starts to decline $[3,6]$.

In adults, the human gut microbiota appears to have a leading phylogenetic core [7]. It was possible, by using the $16 \mathrm{~S}$ rDNA sequencing technique to identify Gram-negative Bacteroidetes, Gram-positive Firmicutes, and Gram-positive Actinobacteria as the dominant phyla [8]. Arumugam and collaborators [9] by applying direct metagenomic sequencing methods have identified and defined three clusters/enterotypes, each characterised by a specific set of networked bacterial genera-the Bacteroides-, the Prevotella- and the Ruminococcus (Figure 1). This research highlights this phenomenon as occurring worldwide; although, as it was mentioned before, everyone's microbiota profile is unique, all humans share a common pattern of gut microbiota. Usually, however, the composition of the basic intestinal microflora is stable during adulthood [1,10], at least until the elderly age (those over 60 years). With advancing age, microbial diversity, and composition is primarily driven by dietary factors and the microbiota, may significantly influence the inflammatory tone and health status immune function, which declines, increasing the number of facultative anaerobes, shifting the ratio of Bacteroides to firmicutes species, and marked decrease in bifidobacteria [11,12].
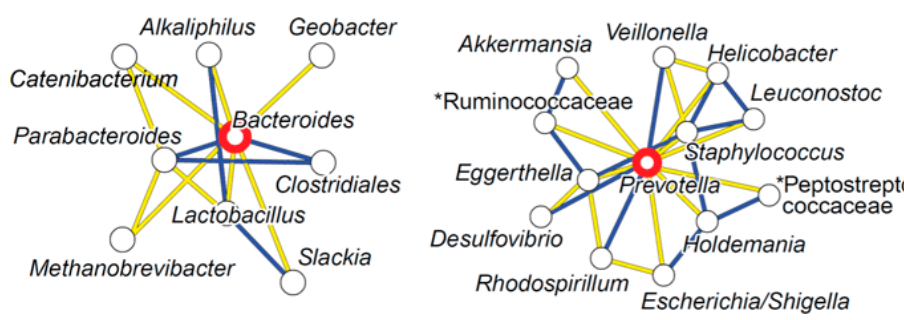

Main contributors

Genera co-occuring with main contributors

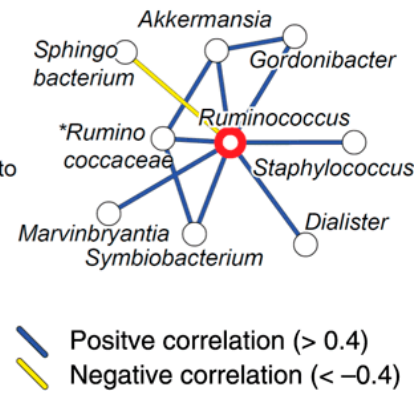

Figure 1. The human gut microbiota-main enterotypes. Co-occurrence networks of the three enterotypes. Unclassified genera under a higher rank are marked by asterisks [1,9]. Adapted from Arumugam et al. [9].

The "colonisation resistance" or beneficial usage of intestinal microflora, is considered the "barrier effect", a mechanism used by the autochthonous gut bacteria to maintain their existence and confer protection against ingested microorganisms, including pathogens [13]. So, manipulation of the gut microflora by increasing the relative number of "helpful bacteria", will beneficially influence the immune function, digestion, metabolism, and brain-gut communication [14]. Alterations in gut microbiota diversity may result in several disorders and diseases that can be treated with several drugs, that do not always work and are cost-effective, and inconvenient for common use. Therefore, a simple, low-cost, friendly, and natural way to improve host health has become a critical issue in the present day. In this perspective, probiotics tend to serve as bio-supplement to the host microflora and provide protection against various enteric pathogens [15].

Probiotics-a word of the modern era, the denotation "for life" —are live microorganisms that are intended to have health benefits when consumed or applied to the human body [16]. They can be found, naturally, in yogurt and other fermented foods and beverages. The microbiota of fermented products is an intricate microbial community made of indigenous microorganisms inherently associated with the raw materials and/or those that are present on the equipment and surfaces of processing sites where chosen microorganisms may be used as starter cultures [17].

Supplementation with probiotics, prebiotics, and synbiotics has shown promising results against various enteric pathogens due to their unique ability to compete with pathogenic microbiota for adhesion sites, to alienate pathogens, or to stimulate, modulate and regulate the host's immune response by initiating the activation of specific genes in and outside the host intestinal tract. Probiotics have also been shown to regulate fat storage and stimulate intestinal angiogenesis [3]. 
Probiotics are made of good live bacteria and/or yeasts that naturally live in our body [15]. So, for a microbe to be called a probiotic, it must have several characteristics. These include (i) survive in our intestine after ingestion (being eaten); (ii) have a proven benefit and (iii) be safely consumed. Probiotics are also able to improve gut barrier function, competing with pathogenic microbiota for adhesion to the gut and improving their colonisation [15].

Probiotics may contain a variety of microorganisms. The most common are bacteria that belong to groups called lactobacilli, lactococci, and bifidobacteria [18]. Other bacteria may also be used as probiotics, like Pediococcus and Streptococcus $[19,20]$ and so may yeasts of the genera Saccharomyces like Saccharomyces boulardii [21] (Figure 2).

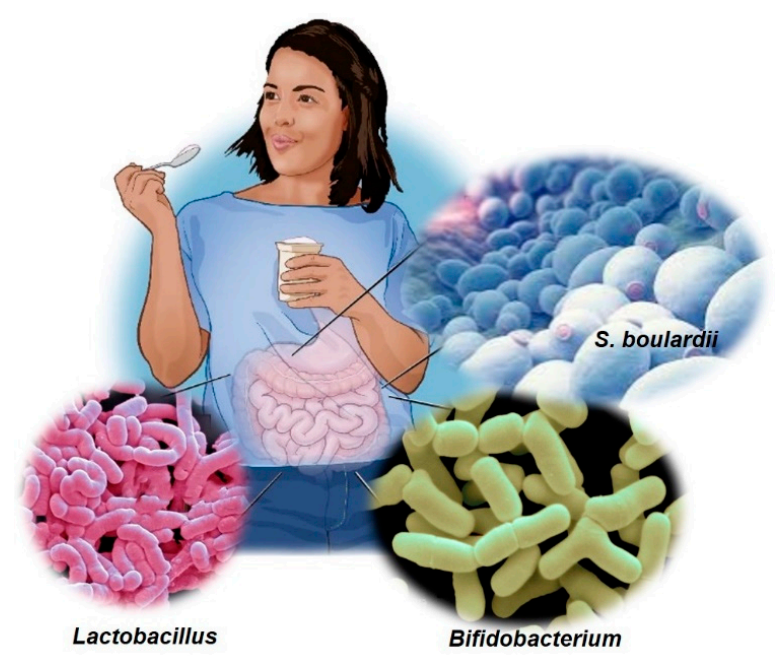

Figure 2. Probiotics are made of both bacteria and yeast. Common probiotic bacteria can include Lactobacillus and Bifidobacterium. The most common yeast found in probiotics is Saccharomyces boulardii [22].

In this huge world of biotics, besides probiotics in the literature also appears the denominations of "postbiotics", "prebiotics", and "symbiotics". Postbiotics are the latest member of the biotics family. This denomination refers to bioactive compounds produced during a fermentation process by food-grade microorganisms. Postbiotics include microbial cells, cell constituents, and metabolites [23] such as short-chain fatty acids (SCFAs), functional proteins, secreted polysaccharides, extracellular polysaccharides (EPS), cell lysates, teichoic acid, peptidoglycan-derived muropeptides, and pili-type structures [24,25]. These compounds are resistant to hydrolysis by mammalian enzymes [3], and are described as also having the proposed health effects of the addition of probiotics. Postbiotics can be divided into paraprobiotics (also called ghost or inactivated probiotics) that are "non-viable microbial cells, intact or broken, or crude cell extracts which when administered in sufficient amounts, confer benefits on the human consumer", like $S$. boulardii, that can enhance barrier function against species, and improves angiogenesis in vitro and in vivo in epithelial cells by activation of $\alpha 2 \beta 1$ integrin collagen receptors [26]; and probioceuticals/probiotaceuticals which defines probiotic resulting factors such as reuterin from Lactobacillus reuteri [27]. The denomination of FIFs (fortified infant foods) can also be used to designate "infant or follow-on formula" that has been fermented with lactic acid-producing or other bacteria and in most cases does not contain viable bacteria [28].

Prebiotics are some nutrients that modify the gut microbial flora. They can change the microbiota composition by stimulating the growth of certain species, thus promoting health benefits in the host $[23,29]$. They are not easily digested by humans although possess a selective function in the stimulation of growth or activity of beneficial bacteria in the gut [30]. Insulin, oligofructose, and fructooligosaccharides (FOS), as well as galactose-containing and xylose-containing oligosaccharides, are some of the commonly known prebiotics [3,31]. Prebiotics are obtained from 
sources like vegetables, fruits, and grains; They do not serve only as an energy source but also have health benefits acting as anti-inflammatory agents and reducing the symptoms associated with intestinal bowel disorders, and preventing colon cancer [32].

Symbiotics are a fusion of probiotics and prebiotics products and help to enhance the survival and the implantation of live microbial dietary supplements in the gut [33]. They contribute considerably to human health. Commercial interest in functional foods containing symbiotics has increased leading to research in this area focused on developing new health-promoting foods and drinks [3].

\section{Probiotics in Non-Dairy Fermented Beverages}

The major source of probiotics is fermented dairy products, however, a study in 2014 published in Food Microbiology [34] isolated bacteria from red wine and tested them for probiotic characteristics. There were isolated and tested 11 strains of Lactic Acid Bacteria (LAB) belonging to Pediococcus pentosaceus, Lactobacillus casei, Lactobacillus plantarum, and Oenococcus oeni. More recently, Le Roy and co-workers [35] performed a study that corroborated the initial one by showing that the occasional glass of red wine could be beneficial for our gut health. The researchers found that our gut microbiomes can be affected by alcoholic beverages including beer, cider, spirits, and both red and white wine.

The diversity of alcoholic, low-alcoholic, and non-alcoholic fermented beverages constitute an integral part of the food culture of many European countries. A diversity of fermented beverages is produced from both edible and inedible raw materials. A wide range of substrates, cereals, fruits, and vegetables are used for its production. So, in the following topics of this article we will review the recent findings of the use of probiotics, prebiotics and symbiotics originated from fermented non-dairy beverages, namely wine, beer, kombucha, among others.

\subsection{Yeasts as Probiotics in Alcoholic Drinks}

The only yeast referred to as a probiotic for a long time has been Saccharomyces cerevisiae var. boulardii [36]. This yeast (S. boulardii) has exceptional physiological properties (tolerance to variations in $\mathrm{pH}$, temperature, and ambient stresses) [37]. Several clinical studies have been done presenting S. boulardii as an exceptional organism that inhibits pathogens $[38,39]$. The mechanism of elimination of the pathogenic bacteria is mainly attributed to the adhesion proteins of $S$. boulardii that bind to bacteria and inhibit their adhesion to the mucous-intestinal membrane [40]. However, other beneficial actions can be pointed out: Within the lumen of the intestine, S. boulardii degrades toxins of pathogens, modulates normal microbiota, and preserves normal intestinal physiology. S. boulardii also restores short-chain fatty acid (SCFA) normal balance and increases secretory $\operatorname{IgA}$ (sIgA) levels or act as an immune regulator by influencing cytokine levels [41], Figure 3. 


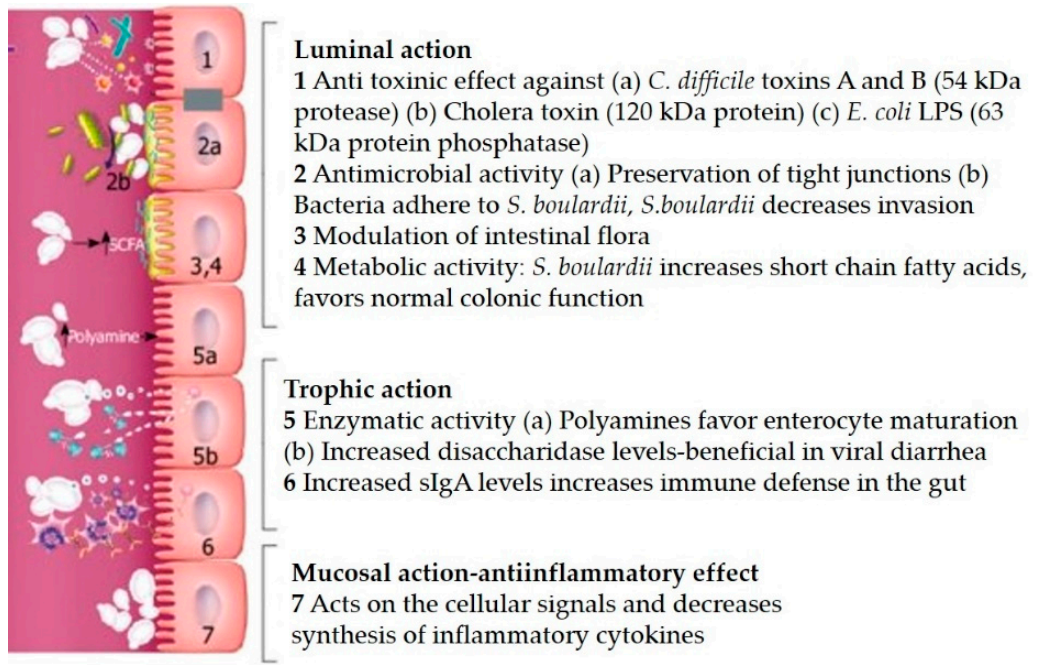

Figure 3. Schematic of the intestinal tract, illustrating the different potential mechanisms of action of Saccharomyces boulardii. Adapted from McFarland [41].

So, there is an increasing interest in the probiotic potential of yeasts, as one could infer from the increasing number of articles on PubMed: using the keywords "probiotic" and "yeast". Only in 2020, 138 articles were published, in a total of 1595 results from 1991 to the recent year (Figure 4A).

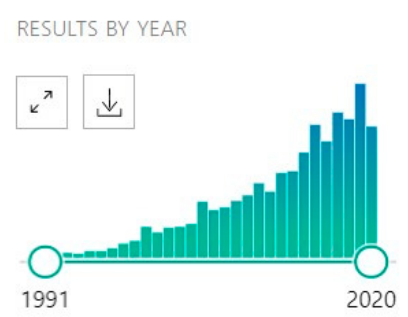

(A)

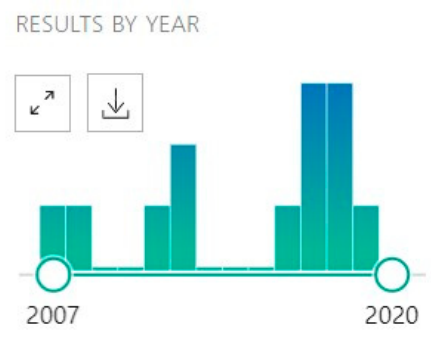

(B)

Figure 4. (A)—Number of articles on PubMed: using the keywords "probiotic" and "yeast", from 1995 to 2020. Data retrieved from https://pubmed.ncbi.nlm.nih.gov/?term=probiotic+yeast (B)-Number of articles on PubMed: using the keywords "probiotic" and "yeast" and "wine", data retrieved from https://pubmed.ncbi.nlm.nih.gov/?term=probiotic+yeast+wine. Accessed 23 September 2020.

If the search terms included wine (probiotic wine yeast), only 12 results were found, published between 2007 and 2019 with the distribution in Figure 4B. The first article that appears was written by Fleet in 2007 [42] and it includes a topic about "Probiotic and other health benefits". The article already mentions $S$. cerevisiae var boulardii as a possible candidate for being used as a probiotic. Besides mentioning its advantages, also mention its negative aspects " $(\ldots)$ When incorporated into some products, it caused gassy, ethanolic spoilage and off-flavours ( ... )" and also reports the occurrence of fungemia infections caused by $S$. boulardii [42,43].

In 2008, MacKenzie and co-workers [44] studied ten medically important S. cerevisiae strains, comprising six clinical isolates of $S$. cerevisiae and four probiotic strains of $S$. boulardii. These yeast strains were characterised at the genetic and metabolic levels and compared with non-medical, commercial yeast strains used in baking and winemaking. One of the strains studied was the S. cerevisiae CECT 1482, a wine strain isolated in Spain. In Figure 2 is possible to see the boot-strapped neighbour-joining cladogram of rDNA ITS1 sequences. Based on ITS1 sequence differences is possible to see that the probiotic strains showed less divergence than the clinical isolates. However, the fact that the S. boulardii ITS1 sequences remained like those from other $S$. cerevisiae strains further reinforced the conspecificity 
of S. boulardii with S. cerevisiae, including that isolated from wine (Sc CECT 1482, in red colour in the cladogram, Figure 5).

Corroborating the ulterior finding, and according to Sen and Mansell [45], S. boulardii and S. cerevisiae are genetically similar, each containing 16 chromosomes with greater than $99 \%$ relatedness [46]. Some of the important differences include those in the genes expressing some flocculation proteins, which contribute to a different adhesion profile of $S$. boulardii when compared to S. cerevisiae [47].

There are also some interesting works about the searching of probiotics yeasts in beer. Capece et al. [48] tested a probiotic strain of S. cerevisiae var. boulardii, in mixed cultures with selected S. cerevisiae strains, during wort fermentation. Among several particularities it was evaluated the potential of surviving until the end of the fermentative process, of S. boulardii strain, aiming to select a starter culture for production of an unfiltered and unpasteurised beer with potential probiotic activity.

A traditional Mexican alcoholic beverage denominated Pulque, produced by fermentation of the fresh sap known as "aguamiel", extracted from some species of agave plants [49] can also possess probiotic yeasts. Páez-Lerma et al. [50] isolated yeast species from Agave duranguesis fermentation in different regions of Mexico, and the most predominant species were Kluyveromyces marxianus, Torulaspora delbrueckii, Pichia fermentans, and Candida diversa. Among these, T. delbrueckii, also isolated from grapes and fermented grape must [51], showed probiotic characteristics such as resistance to gastric and intestinal conditions, growth at $37^{\circ} \mathrm{C}$ [48].

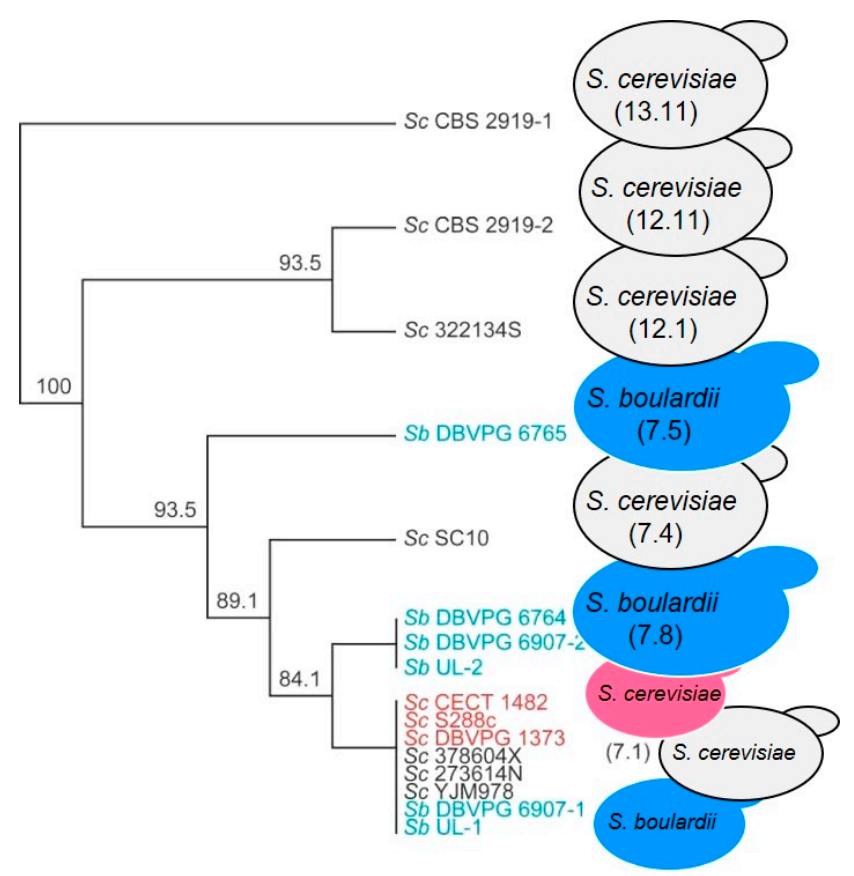

Figure 5. Boot-strapped neighbor-joining cladogram of rDNA ITS1 sequences. Bootstrap values (\%) are indicated at each node in the tree. S. boulardii (Sb); S. cerevisiae (Sc). Clinical strains are in black, probiotic strains in blue, and non-medical strains are indicated in red colour. Adapted from MacKenzie et al. [44].

Therefore, the yeasts isolated from alcoholic drinks may represent a good alternative to probiotic bacteria because they are immune to the antibiotic effects, avoiding the occurrence of antibiotic-associated intestinal diseases, and limiting the development of antibiotic resistance [51]. These reasons, among others, already mentioned, led scientists to focus their interest on the study of other yeast species, rather than S. boulardii, with probiotic properties. So, numerous yeasts, from Debaryomyces, Kluyveromyces, Yarrowia, and Torulaspora genus, isolated from different environments, have been proposed as microorganisms with potential health benefits [52-55] as also some species of the genera Candida, Pichia, Hanseniaspora, and Metschnikowia [56,57], and other non-Saccharomyces species such as Lachancea thermotolerans (isolated from moss on oak), and Metschnikowia ziziphicola 
(isolated from beech tree bark) [50]. Moreover, Debaryomyces hansenii, Kluyveromyces lactic, among others, was recently approved by the European Food Safety Authority (EFSA) and included on the list of "Qualified Presumption of Safety" (QPS) microorganisms assumed safe [58]. However, until now, only $S$. boulardii is considered a probiotic yeast. The other candidate yeast species need more in vitro characterisation before their utilisation in human trials [51].

\subsection{Yeasts as Probiotics/Symbiotics in Low/Non-Alcoholic Drinks}

Kombucha tea (Medusomyces gisevii Lindau) is a fermented sweetened tea, thought to have originated in Manchuria, China, and it is a beverage with probiotic characteristics. The microorganisms presented in the fermented tea, Medusomyces gisevii Lindau, represents a symbiotic microbial community also denominated as "tea fungus". During tea fermentation, the added sugar is converted into organic acids and ethanol by a symbiotic community of microorganisms named SCOBY (Symbiotic Culture of Bacteria and Yeast). Ethanol and the low $\mathrm{pH}$ due to the organic acids formed during tea fermentation protect SCOBY from the colonisation of other microorganisms [59]. The yeast present in this symbiotic community can vary and may include yeast of the genera Brettanomyces/Dekkera, Pichia, Schizosaccharomyces, Torulaspora, and Zygosaccharomyces [60], while the bacteria community that we can find in kombucha are species of Acetobacter nitrogenifigens sp. nov, A. intermedius, sp. nov., Gluconacetobacter xylinus, and G. kombuchae sp. nov. [61,62].

A slightly alcoholic fermented beverage known as Water kefir, or "tepache de tibicos" can also be a probiotic/symbiotic drink. It is made with sugar cane and some fruits as figs or lemons [63]. The starter cultures used in the fermentation are grains composed of water and polysaccharides and different microorganisms. Martínez-Torres, et al. [64] found the occurrence of S. cerevisiae (responsible for alcoholic fermentation) in the early stage of the process and other yeasts as Candida californica and Pichia membranefaciens.

Boza is a cereal-based fermented beverage with recognised probiotic properties. Sensorially it is like a millet beer and its origin can be traced back to 8000-9000 years ago when cereals were first fermented by man to produce beverages. It is made from wheat or rice semolina or a combination of rye, oat, barley, and millet flour for the best quality and taste [65]. In Boza's preparation, two fermentation processes occur, lactic acid fermentation by LAB and alcohol fermentation by yeasts. Microbiota identification of boza shows that it mainly consists of LAB (Lactobacillus plantarum, Lb. acidophilus, Lb. fermentum, Lb. coprophilus, Leuconostoc raffinolactis, Ln. mesenteroides, and Ln. brevis) yeasts (S. cerevisiae, Candida tropicalis, Candida glabrata) and fungi (Geotrichum penicillatum and G. candidum) [66].

Kvass is an extremely popular beverage in the countries of the former Soviet Union, especially in Russia. It contains carbohydrates-maltose, maltotriose, glucose, and fructose-, proteins and amino acids, lactic and acetic acid, ethanol, minerals, and vitamins originating from the raw materials or the microbial metabolic activity. Kvass is rich in microbiota consisting of viable yeasts and LAB [67]. Its microbiota of fermentation consists of LAB (Lb. casei, Ln. mesenteroides) and yeasts (S. cerevisiae) [66].

\subsection{Lactic Acid Bacteria (LAB) as Probiotics}

Beyond food probiotics such as yogurt, acidophilus milk, kefir, sourdough bread, soft cheese, miso soup, sauerkraut, sour pickles, tempeh among many other fermented foods by LAB [68-70]. there are many probiotics formulations available nowadays worldwide, as supplements, marketed mostly in capsules, tablets, powder, and liquid forms [71,72]. These formulations are generally made up of several strains of LAB, varying in number (from one to 13 strains) within each trademark. There are many probiotics formulations available nowadays worldwide, marketed mostly in the form of capsules and sachets. Protexin Balance, Protexin Protect, Protexin Restore, Protexin Vitality, Protexin Biokult from Prebiotech Healthcare [73], Ultrabiotique Equilibre 30 jours from Nutrisanté laboratories [74], Zumub Advanced Probioticare from Zumub [75], Digest Ultra Probiotics from Eladiet [76], are many of the examples of LAB probiotics available. We should underline the reduced expression of other 
bacterial groups as probiotics, with only one strain of Bacillus subtilis appearing in a formulation. There is also a trademark association with yeasts, Saccharomyces boulardii strains, which can also be sold alone, and due its importance has already been presented in the previous point of this article.

The LAB strains found in the aforementioned probiotic formulations belong to the following species Bifidobacterium bifidum, Bifidobacterium breve, Bifidobacterium infantis, Bifidobacterium longum, Lactobacillus acidophilus, Lactobacillus bulgaricus, Lactobacillus casei, Lactobacillus delbrueckii ssp., Lactobacillus helveticus, Lactococcus lactis ssp. lactis, Lactobacillus paracasei, Lactobacillus plantarum, Lactobacillus rhamnosus, Lactobacillus salivarius, Lactococcus lactis, Enterococcus faecium, and Streptococcus thermophilus.

As observed for yeasts at the same period, there is a high number of articles in PubMed containing simultaneously probiotics and lactic acid bacteria as keywords in the search, being 188 articles published only in 2020, in a total of 2067 results from 1991 to the recent year (Figure 6A) and also a very small number of papers containing additionally wine as another keyword in the search (Figure 6B)

If the search terms included wine (wine probiotics lactic acid bacteria), only 14 results were found, published between 2010 and 2020 with the distribution shown in Figure 6B. The first article that appears involving a LAB isolated from wine was written by Foligné and co-authors in 2010 [77] approaching probiotic properties of non-conventional lactic acid bacteria, namely by Oenococcus oeni. The authors concluded that due to the 'natural' tolerance towards acid, ethanol, and phenolic compounds of $O$. oen $i$ strains combined with a measurable immunomodulatory potential, selected strains isolated from wine may be used as live probiotics.

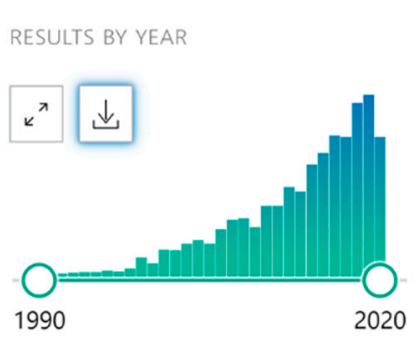

(A)

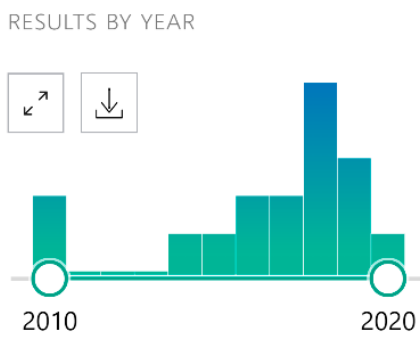

(B)

Figure 6. (A) -Number of articles on PubMed: using the keywords "probiotic" and "lactic acid bacteria", from 1995 to 2020. Data retrieved from https://pubmed.ncbi.nlm.nih.gov/?term=〈T1 $\backslash$ textquotedblrightprobiotics+and+lactic+acid+bacteria $\backslash \mathrm{T} 1 \backslash$ textquotedblright. (B)-Number of articles on PubMed: using the keywords "probiotics" and "lactic acid bacteria" and "wine", data retrieved from https://pubmed.ncbi.nlm.nih.gov/?term=〈T1 \textquotedblrightprobiotics $\backslash$ T1 $\backslash$ textquotedblright + and $\backslash$

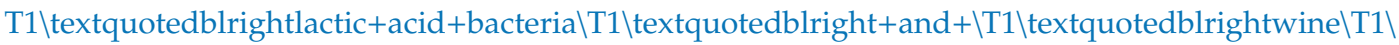
textquotedblright. Accessed 15 October 2020.

Raw materials, including cereals, millets, legumes, fruits, and vegetables are used worldwide to make several traditional non-dairy fermented beverages such as Boza, Pozol, Bushera, Mahewu, and Togwa, among others, being also good sources of probiotics and prebiotics [78,79].

From Boza, a Turkish traditional fermented drink, made by fermenting various grains such as maize and wheat, Kivanc et al. [80] isolated many strains of Lactobacillus plantarum that showed antagonistic activity against pathogenic bacteria such as Listeria monocytogenes, Bacillus cereus, B. subtilis, Yersinia enterocolitica, E. coli, Pseudomonas aeruginosa, Salmonella enterica subsp. enterica Serovar Typhimurium and Klebsiella pneumoniae.

Oluwajoba et al. [81] isolated probiotic LAB strains belonging to Lactobacillus, Pediococcus, and Lactococcus species with antimicrobial activity against the referent strains of Staphylococcus aureus, Escherichia coli, Pseudomonas aeruginosa, and Enterococcus faecalis, from Kunu-zaki, a Nigerian traditional fermented drink made from non-germinated sorghum and millet cereal grains. 
From Hardaliye, a Turkish non-alcoholic fermented beverage produced from a mixture of red grapes (Vitis vinifera), crushed mustard seeds (Sinapis alba), and dried sour cherry leaves (Prunus cerasus) Amoutzopoulos et al. [82] observed a LAB population constituted exclusively by Lactobacillus species, and Arici and Coskun [83] were able to isolate and identify 15 strains as Lactobacillus casei subsp. pseudoplantarum, six as Lactobacillus pontis, three as Lactobacillus brevis, three as Lactobacillus acetotolerans, three as Lactobacillus sanfransisco, and three as Lactobacillus vaccinostercus.

Considering water kefir, a sour, alcoholic, and fruity fermented beverage, the most important LAB species present and identified using molecular approaches were Lactobacillus casei/paracasei, Lactobacillus harbinensis, Lactobacillus hilgardii, Bifidobacterium psychraerophilum/crudilactis [84], Lactobacillus nagelii, Lactobacillus species similar to Lactobacillus hordei/mali, Bifidobacterium aquikefiri and a novel Oenococcus species related to Oenococcus oeni and Oenococcus kitaharae under the name of Candidatus Oenococcus aquikefiri [85].

From another beverage named Makgeolli, a traditional Korean alcoholic beverage, Park et al. [86] isolated 17 different LAB strains identified as Pediococcus acidilactici (8), P. pentosaceus (6), Lactobacillus curvatus (2), and L. curstorum (1). Most strains presented immunomodulatory effects, and some exhibited high acid tolerance properties and good bile acid tolerance. One strain of P. acidilactici (PA5) also revealed a high cell adhesion, making it a promising candidate as a probiotic for further food industry applications.

Palm wine is a traditional beverage made using the sap collected from different palm trees species according to their geographic origin, being consumed in different parts of the world (Borneo, India, Mexico, Cameroon, and Côte d'Ivoire) known with local and different designations [87-89]. Using a molecular approach by next-generation sequencing of the V3-V4 regions of the 16S rRNA gene to analyse bacterial diversity and population dynamics during the fermentation process of Tuba (palm wine) samples from laboratory-controlled conditions and commercial samples, Astudillo-Melgar et al. [88] showed that Fructobacillus was the main genus in all the samples following by Leuconostoc, inside the LAB group. Also with molecular techniques namely $16 S$ rRNA gene sequencing and typification by (GTG)5-PCR fingerprinting [89] identified their LAB isolates as Fructobacillus durionis (40.33\%) and Leuconostoc mesenteroides (45.66\%), with Leuconostoc pseudomesenteroides, Lactobacillus paracasei, Lactobacillus fermentum, Weissella cibaria, Enterococcus casseliflavus and Lactococcus lactis occurring occasionally. Fossi et al. [87] isolated 3 bacteriocinogenic LAB strains identified as Lactobacillus plantarum, Lactobacillus rhamnosus, and Lactobacillus brevis, that showed high antimicrobial activity against Escherichia coli, Salmonella enterica, Salmonella enterica subsp. enterica Serovar Typhimurium, Staphylococcus aureus, and Listeria monocytogenes.

\subsection{Malolactic Bacteria as a Source of $L A B$ Probiotics}

In wine, LAB performs a second fermentation consisting of decarboxylation of L-malic acid to L-lactic acid, designated by malolactic fermentation (MLF). In a recent review work, Inês and Falco [90] collected a panoply of bibliographic references that bring together until the date, the different described species, responsible for MLF.

Thus it is possible to find the following species of LAB: (i) Facultative Heterofermentative Bacilli (Lactobacillus casei, Lb. coryniformis, Lb. curvatus, Lb. homohoichii, Lb. paracasei, Lb. pentosus, Lb. plantarum, Lb. sakei, Lb. zeae, Lb. nagelli, Lb. diolivorans); (ii) Heterofermentative Bacilli (Lactobacillus brevis, $L b$. buchnerii, $L b$. collinoides, Lb. fermentum, Lb. fructivorans, Lb. hilgardii, Lb. kunkeei, Lb. sanfrancisensis, Lactobacillus spp., Lb. vacinostercus); (iii) Homofermentative Bacilli (Lactobacillus delbrueckii, Lb. jensenii, Lb. mali, Lb. vini); (iv) Homofermentative Cocci (Pediococcus acidilactici, Pc. damnosus, Pc. dextrinicus, Pc. inopinatus, Pc. parvulus, Pc. pentosaceus, Pediococcus spp., Lactococcus lactis, Lactococcus spp., Enterococcus spp.) and Heterofermentative Cocci (Leuconostoc citrovorum, Leuc. mesenteroides subsp. dextranicum, Leuc. mesenteroides subsp. mesenteroides, Leuconostoc spp., Weissella confusa, W. paramesenteroides, Weissella spp., W. uvarum, Oenococcus oeni). 
As can be seen from the great diversity of species responsible for MLF and already isolated, wine is an excellent source of lactic bacteria to be used as probiotics. Furthermore, many of these species are already used in the formulations of the probiotics previously presented. There is therefore a need to investigate strains of other species not yet explored that may have a high probiotic potential.

Also, according to some authors, as wine is a hostile environment (acid, ethanol, and phenolic compounds) these strains present natural tolerance towards these conditions, thus being additional features that increase their potential to be live probiotics [91].

In the study carried out by García-Ruiz et al. [34] probiotic properties of 11 oenological LAB strains belonging to Lactobacillus and Pediococcus genera, and Oenococcus oeni and two probiotic reference strains (Lactobacillus plantarum CLC 17 and Lactobacillus fermentum CECT5716 were evaluated. The authors investigated many probiotic features including saliva and acid resistance, bile tolerance, and exopolysaccharides production and they found that the Lactobacillus and Pediococcus strains showed high resistance to lysozyme (conditions simulating the in vivo dilution by saliva) and were capable of surviving at low $\mathrm{pH}$ values of 1.8 and bile salts (simulating stomach and small intestine, respectively), suggesting good adaptation of the wine strains to gastrointestinal conditions.

The same authors [34] also evaluated the ability of the wine strains to adhere to the intestinal mucosa and the inhibition of the adhesion of Escherichia coli to human intestinal cells, using Caco-2 cells. They found a Pediococcus pentosaceus strain that showed a higher percentage of adhesion to intestinal cells and high anti-adhesion activity against E. coli even higher than that shown by the probiotic reference strains, which support this wine LAB strain as a potential probiotic.

In another work, with strains of O.oeni, beyond their good adaptation to gastrointestinal conditions and high bile resistance abilities inferred by exhibited good survival abilities at low $\mathrm{pH}$ values ( $\mathrm{pH}$ 1.8) and bile salts (1\%), Su et al. [91] also verified the effectiveness of O. oeni strains in the defence against in vitro oxidative stress, so putatively serving as defensive agents in the intestinal microbial ecosystem and overcome exogenous and endogenous oxidative stress.

Foligné et al. [77] refer that some biochemical or physiological characteristics mentioned above, and others shown by different authors, could offer some advantages in additional applications. Additionally, bacteria considered either "beneficial" or "unsuitable" for winemaking may have health-promoting potential. These features are: (i) wine LAB are highly resistant to an acidic environment, alcoholic and sulphur dioxide stress; (ii) some wine LAB can produce EPS (responsible for the attenuation of colitis by probiotic strains, involved in resistance to bile salts and low $\mathrm{pH}$, adhesion to intestinal epithelial cells and can reduce biofilm formation of pathogens (iii) some wine LAB can adhere to epithelial cells, characteristic that is still believed to have some relevance in probiotic functionality (iv) some wine LAB are known to secrete bacteriocins, important as a food preservative but also may play a role in human and animal health with activities against Listeria monocytogenes and Enterococci; (v) wine LAB, similarly as some other strains of lactobacilli and bifidobacteria do modulate cytokine production by monocytes and lymphocytes. The intake of these strains in sufficient quantities may divert the immune system into a regulatory or tolerance mode, possibly useful in the prevention or treatment of atopic disease or inflammatory bowel diseases.

Oenological strains as probiotic may only have a probiotic potential outside their natural habitat and should better exist as a supplement rather than in functional food [77].

\section{Prebiotics Derived from Wine and Other Fermented Beverages}

Consumers worldwide are increasingly aware of the relation between nutrition and health. The major segment of this market includes foods designed to increase gut health such as prebiotics. Prebiotics are defined in 1995 by Gibson and Roberfroid [92] as "nondigestible food constituents that beneficially affect the host by selectively stimulating the growth and/or activity of one or a limited number of bacterial species already resident in the colon". Later, Gibson et al. [93] defined prebiotics as "a selectively fermented ingredient that allows specific changes, both in the composition and/or activity in the gastrointestinal microflora, that confer benefits upon host well-being and health". 
The International Scientific Association for Prebiotics and Probiotics (ISAPP) in 2010 extended the definition to contain also the functionality of the prebiotics: "a selectively fermented ingredient that results in specific changes in the composition and/or activity of the gastrointestinal microbiota, thus conferring benefit(s) upon host health" [94]. Prebiotic dietary fibers turn into carbon sources for primary and secondary fermentation pathways in the colon and maintain digestive health in several ways. Prebiotics are generally low or nondigestible oligosaccharides and particularly fructooligosaccharides and inulin are usually agreed-upon prebiotics, Table 1. Other prebiotic dietary fibers are beta-glucans [95], isomaltooligosaccharides, guar gum, maltodextrin, xylooligosaccharides (XOS), and arabinooligosaccharides. Resistant starch can also promote health by producing a high level of butyrate; so, it has been suggested to be also classified as a prebiotic [96]. They are classified as prebiotics since they are not hydrolysed or absorbed in the upper part of the gastrointestinal tract, and affect beneficially the selective stimulation of the growth of bacterial present in the colon and may inhibit pathogens, and therefore they can have health benefits [92,97]. Prebiotics of several types occurs naturally in asparagus, leeks, onions, soybeans, wheat, oats, Jerusalem artichokes, garlic, barley, bananas, rye-flour, and chicory $[98,99]$. In most of these foods, the prebiotics concentrations range between $0.3 \%$ and $6 \%$ of fresh weight; for chicory, these values are between $5 \%$ and $10 \%$ while in Jerusalem artichoke they can reach up to $20 \%$.

Table 1. Individual prebiotics and their sources fruit or vegetable source. Adapted from Shigwedha et al. [100].

\begin{tabular}{|c|c|}
\hline Prebiotics & Primary Source \\
\hline Cellulose/hemicellulose/lignin/waxes & Plant foods \\
\hline Guar gum & Guar bean (legume) \\
\hline Inulin/oligofructose/Fructooligosaccharides (FOS) & $\begin{array}{c}\text { Chicory root, wheat, Jerusalem artichoke, banana, onions, } \\
\text { leeks, garlic }\end{array}$ \\
\hline Chitooligosaccharides (COS) & Derivative of chitin \\
\hline Xylooligosaccharides (XOS) & Corn cobs, rice hulls, straws, bagasse, malt cakes, and bran \\
\hline Soybean oligosaccharides & Soybean \\
\hline$\beta$-Glucan and oat bran & Oats and barley \\
\hline Pectin, gums & Plant foods \\
\hline Resistant dextrin & Corn and wheat \\
\hline Resistant starch & Plant foods \\
\hline Soluble corn fiber & Corn \\
\hline
\end{tabular}

Fructooligosaccharides are mainly present in asparagus, Jerusalem artichoke, chicory, sugar beet, onion, garlic, barley, wheat, honey, banana, tomato, and rye in a concentration ranging from $0.15 \%$ to $0.75 \%$ of FOS in natural food [100-102]. Chemically, fructooligosaccharides are short- and medium-length chains of $\beta$-D-D-fructans in which fructosyl units are bound by $\beta-2-1$ osidic linkage. Fructooligosaccharides are not digested by the human gastrointestinal tract, obtained from plant sources, and when they reach the colon, they beneficially stimulate the growth and strengthening of specific bacteria in the intestine [103].

Inulin is a heterogeneous blend of fructose polymers found in nature as plant storage polysaccharides (degree of polymerisation, DP < 10) [104] such as in wheat $(1.0-3.8 \mathrm{~g} / 100 \mathrm{~g}$ ), raw onion pulp (1.1-7.5 g/100 g), garlic (9.0-16.0 g/100 g), Jerusalem artichoke tuber (16.0-20.0 g/100 g), chicory $\operatorname{root}(35.7-47.6 \mathrm{~g} / 100 \mathrm{~g})$, asparagus raw (2.0-3.0 g/100 g) and barley (0.5-1.0 g/100 g) [105].

Beta-glucans ( $\beta$-glucans) are linear polysaccharides formed by D-glucopyranosyl units with a mixture of $\beta-(1,3)$ and $\beta$ - $(1,4)$ glycosidic linkages. $\beta$-glucans are chemical, non-starch polysaccharides with repeating glucose residues in linear chains or multiply branched structures with the glucose units being branched in diverse ways depending upon the source of origin. Cereal $\beta$-glucans chains are linear, composed by consecutive linked (via $\beta-1-3$ linkages) of cellulosic oligomers, i.e., segments of $\beta-1-4$ linked glucose residues $[106,107]$. For microbial $\beta$-glucans, the $\beta$-D-glucopyranose units are linked together through $\beta-(1,3)$ linkages to form a long backbone, whereas side chains mostly arise through $\beta$ - $(1,6)$ linkages [108]. $\beta$-glucans are soluble fibers in the cereal grains endosperm cell walls 
such as in oat and barley (up to $7 \%$ ) or in mushrooms, algae, and other marine plants $[95,109,110]$, they can also occur in rye and rice [111].

Isomaltulose is a naturally occurring disaccharide composed of $\alpha-1,6$-linked glucose and fructose, and it is considered a prebiotic [112]. It occurs naturally in honey and sugarcane juice and products derived thereof [113].

Xylooligosaccharides is a prebiotic with health benefits [114] and they are composed of sugar oligomers of xylose units and are found naturally in fruits, honey, vegetables, and bamboo shoots [115].

Phenolic compounds are naturally occurring secondary metabolites of plants that comprise of several compounds that are classified mainly based on structure [116]. Plant-based beverages, comprising fruits, vegetables, and wine, are rich sources of dietary polyphenols. Preclinical and clinical studies suggest that polyphenols are also able to express prebiotic properties and exert antimicrobial activities against pathogenic gut microflora [117-120]. Parkar et al. [121] showed the inhibitory effect of citrus polyphenols such as hesperetin, naringenin, poncirin, and diosmetin on the growth of the human gut bacteria. Also, wine phenolic compounds have been suggested to modulate gut microbiota inducing prebiotic-like effects of the growth of beneficial bacteria and the inhibition of pathogenic bacteria [122-124]. During wine consumption, for example, oligomeric procyanidins arrive in the colon [125]. The red wine phenolic compounds may modify the gut microbial composition by their antimicrobial properties inhibiting non-beneficial bacteria from the human microbiota and potentiate the growth of probiotic bacteria such as bifidobacteria, and this, in turn, may affect their functional relations with the host [126]. Likewise, intestinal bacteria metabolise wine polyphenols into specific bioavailable metabolites. The beneficial actions described for wine have been recognised to these phenolic microbial-derived metabolites rather than the initial precursors present in wine $[126,127]$.

Non-dairy probiotic fermented beverages, using a variety of subtracts, such as cereals, soy milk, fruit and vegetable juices, have become known for their health-promoting qualities. These fermented beverages are principally attractive due to their absence of dairy allergens such as lactose, low cholesterol content, and vegan friendly [128].

To this end, cereal-based beverages have natural prebiotics due to the existence of indigestible fibers. Cereals such as oats, wheat, maize, rye, millet, sorghum, barley, or rice are used to produce cereal-based fermented beverages. Oats, a noteworthy wellspring of $\beta$-glucans which can lessen LDL cholesterol, are referred to work as a prebiotic by boosting bifidobacteria numbers in the gut. Processing conditions such as fermentation could support the development of a cereal beverage with high beta-glucan values [129]. Oat-fermented beverage with high $\beta$-glucans with banana was studied as an alternative from milk proteins or lactose-intolerant people [109]. Barley and malt have also been used as beverage substrates [130].

Many traditional cereal-based fermented beverages exist, both alcoholic and non-alcoholic, and some examples are listed in Table 2 [131-133]. 
Table 2. Cereal fermented beverages. Adapted from Blandino et al. [131].

\begin{tabular}{|c|c|c|c|}
\hline Product & Subtract & Nature of Use & Country \\
\hline Bagni & Millet & Liquid drink & Caucasus \\
\hline Bouza & Wheat & $\begin{array}{l}\text { Thick, acidic, yellow, } \\
\text { alcoholic beverage }\end{array}$ & Egypt \\
\hline Boza & $\begin{array}{l}\text { Wheat, millet, maize, } \\
\text { and other cereals }\end{array}$ & $\begin{array}{l}\text { Thick, sweet, slightly } \\
\text { sour beverage }\end{array}$ & $\begin{array}{l}\text { Albania, Turkey, } \\
\text { Bulgaria, Romania }\end{array}$ \\
\hline Braga & Millet & Liquid drink & Romania \\
\hline Brembali & Rice & $\begin{array}{c}\text { Dark brown alcoholic } \\
\text { drink }\end{array}$ & Indonesia \\
\hline Burukutu & Sorghum & $\begin{array}{l}\text { Alcoholic beverage of } \\
\text { vinegar-like flavour }\end{array}$ & Nigeria, Benin, Ghana \\
\hline Busa & Rice or millet & Liquid drink & Syria, Egypt, Turkestan \\
\hline Busaa & Maise & Alcoholic beverage & Nigeria, Ghana \\
\hline Chikokivana & Maize and millet & Alcoholic beverage & Zimbabwe \\
\hline Chongju & Rice & Alcoholic clear drink & Korea \\
\hline Darassum & Millet & Liquid drink & Mongolia \\
\hline Doro & Finger millet malt & $\begin{array}{l}\text { Colloidal thick alcoholic } \\
\text { drink }\end{array}$ & Zimbabwe \\
\hline Kachasu & Maize & Alcoholic beverage & Zimbabwe \\
\hline Kaffir beer & Kaffir corn & Alcoholic drink & South Africa \\
\hline Khaomak & Rice & Alcoholic sweet beverage & Thailand \\
\hline Mangisi & Millet & $\begin{array}{c}\text { Sweet-sour non-alcoholic } \\
\text { drink }\end{array}$ & Zimbabwe \\
\hline Merissa & Sorghum and millet & Alcoholic drink & Sudan \\
\hline Otika & Sorghum & Alcoholic beverage & Nigeria \\
\hline Pito & $\begin{array}{l}\text { Maize, sorghum, maize, } \\
\text { and sorghum }\end{array}$ & $\begin{array}{c}\text { Alcoholic dark brown } \\
\text { drink }\end{array}$ & Nigeria, Ghana \\
\hline
\end{tabular}

Table 2. Cont.

\begin{tabular}{cccc}
\hline Product & Subtract & Nature of Use & Country \\
\hline Sake & Rice & Alcoholic clear drink & Japan \\
\hline Seketeh & Maize & Alcoholic beverage & Nigeria \\
\hline Shaosinghjiu & Rice & Alcoholic clear beverage & China \\
\hline Sorghum beer & Sorghum, maize & $\begin{array}{c}\text { Liquid drink, acidic, } \\
\text { weakly alcoholic }\end{array}$ & South Africa \\
\hline Takju & Rice, wheat & Alcoholic turbid drink & Korea \\
\hline Talla & Sorghum & Alcoholic drink & Ethiopia \\
\hline Tapai pulut & Rice & Alcoholic dense drink & Malaysia \\
\hline Tapuy & Rice & Sour sweet alcoholic & drink \\
Tesgüino & Maise & Alcoholic beverage & $\begin{array}{c}\text { Northern and } \\
\text { North-Western Mexico }\end{array}$ \\
\hline
\end{tabular}


European barley beer is an example of a cereal-based fermented beverage [132]. In Africa traditional beers diverge from the western-type; they are frequently less carbonated, sour, and have no hop. Examples are pito and burukutu which are brewed simultaneously by fermenting malted or germinated single cereal grains or a mixture of them [134]. Cereal fermentation in Africa and Asia involves mainly the processing of maize, rice, sorghum, and millets [135]. For example, in Zambia and the Democratic Republic of Congo is produced a non-alcoholic spontaneously fermented cereal-based beverage called Munkoyo [136], in Tanzanian is also produced a fermented cereal grains beverage with sorghum, maize, and millet named Togwa [131], in West African is produced a fermented sorghum gruel named Ogi-baba [137]. In Africa and Asia, many types of opaque beers named Tchoukoutou are produced by malting red sorghum [138]. Water-soluble and insoluble arabinoxylans, $\beta$-glucan, oligosaccharides, and resistant starch are cereal indigestible but fermentable dietary carbohydrates, which are used as fermentation substrates for probiotic lactic acid bacteria and could be used to realise the beneficial effect of both the probiotic organisms and imparting prebiotic effects [139].

According to Jovanovic-Malinovskat et al. [140] that make an oligosaccharide profile of 32 fruits (total FOS ranged from nd- $0.89 \mathrm{~g} / 100 \mathrm{~g}$ fresh weight of edible sample) and 41 vegetables (total FOS ranged from nd-3.32 $\mathrm{g} / 100 \mathrm{~g}$ fresh weight of edible sample) observed that in general fruits contained low amounts of total fructooligosaccharides. The content of total oligosaccharides of fruits in a descending order was nectarine $>$ watermelon $>$ pear $>$ raspberry $>$ blueberry and for vegetable was scallion $>$ onion $>$ garlic $>$ leek $>$ spring garlic. The highest content of fructooligosaccharides was found in nectarine $(0.89 \pm 0.031 \mathrm{~g} / 100 \mathrm{~g}$ fresh weight). The vegetable with the highest quantity of fructooligosaccharides was scallion $(3.32 \pm 0.108 \mathrm{~g} / 100 \mathrm{~g}$ fresh weight). According to several authors, beverages formulated with fruit and vegetable juices are promising food matrices to serve as carriers of probiotic bacteria $[141,142]$.

There is a great diversity of fermented beverages produced with fruits from Asia, Africa, and Latin America. Grape/grape juice is perhaps the most fermented beverage (wine) from an economic point of view, there are other fruit fermented beverages such as pineapple in Latin America and jackfruit in Asia [143]. Fermented beverages from agave (Pulque), coconut palm (Taberna), or coyol palm (Tuba) are also produced in Mexico [144-146].

\section{Final Remarks}

Although bacterial colonisation of the human gut evolves and transforms over a lifetime, they are an important part of our microbiome. In the gut, they help modulate the internal environment and play a major role in human health, from defence functions to improving digestion and influencing brain-gut responses, so manipulation of the gut microflora by increasing the relative number of "helpful bacteria", will beneficially influence our body functions. Consequently, a simple, low-cost, friendly, and natural way to improve host health is to ingest probiotics naturally add them to our food-chain.

The microbiota of fermented products is a complex microbial system, and the major source of probiotics are fermented dairy products, nevertheless, alcoholic, low-alcoholic, and non-alcoholic fermented beverages constitute an integral part of the food culture of many world countries and, a huge diversity of fermented beverages is produced with a wide range of substrates such as cereals, fruits, and vegetables. These beverages contain naturally occurring probiotics, prebiotics, and symbiotics, and can be used as a source of these health-promoting components.

Probiotics may contain a variety of microorganisms. The most common are bacteria that belong to groups called Lactobacillus, Lactococcus, and Bifidobacterium. Many articles already describe the beneficial use of yeasts of the genera Saccharomyces like S. boulardii. as, also, other non-Saccharomyces yeasts, usually called "wine-yeasts". Moreover, in wine, we can find a huge number of Lactobacillus species making this drink, and other alcoholic drinks such as Boza and Kvass, an important source of probiotic bacteria. Interestingly, many of these species are already used in the formulations of probiotic of pharmaceutical origin. 
In combination with probiotics, consumers worldwide are increasingly aware of the relation between nutrition, health, and prebiotics "a selectively fermented ingredient that results in specific changes in the composition and/or activity of the gastrointestinal microbiota, thus conferring benefit(s) upon host health". Prebiotics, such as low or nondigestible oligosaccharides and fructooligosaccharides, $\beta$-glucans, isomaltooligosaccharides, guar gum, maltodextrin, xylo-oligosaccharides, and arabinooligosaccharides, among others, selective stimulate the growth of bacterial present in the colon and may inhibit pathogens.

Plant-based beverages, such as wine, are also rich sources of dietary polyphenols that can express prebiotic properties and exert antimicrobial activities against pathogenic gut microflora, once they are capable of inhibiting non-beneficial bacteria from the human microbiota and potentiate the growth of probiotic bacteria such as bifidobacteria.

In conclusion, the inclusion in our daily meals of fermented beverages may contribute significantly -to our health. These beverages will give not only the pleasure of flavoured drinks but also the potential benefits due to their microbial composition.

Funding: This study was funded by the CQ-VR [grant number UIDB/00616/2020 and UIDP/00616/2020], FCT-Portugal, and COMPETE.

Acknowledgments: The authors would like to thank the Chemistry Center (CQ-VR) for the financial support.

Conflicts of Interest: The authors declare no conflict of interest.

\section{References}

1. Aziz, Q.; Dore, J.; Emmanuel, A.; Guarners, F.; Quigley, E.M.M. Gut microbiota and gastrointestinal health: Current concepts and future directions. Neurogastroenterol. Motil. 2013, 25, 4-15. [CrossRef] [PubMed]

2. Slavin, J. Fiber and Prebiotics: Mechanisms and Health Benefits. Nutrients 2013, 5, 1417-1435. [CrossRef] [PubMed]

3. Kerry, R.G.; Patra, J.K.; Gouda, S.; Park, Y.; Shin, H.-S.; Das, G. Benefaction of probiotics for human health: A review. J. Food Drug Anal. 2018, 26, 927-939. [CrossRef]

4. Guarnier, F. The enteric microbiota. In Colloquium Series on Integrated Systems Physiology: From Molecule to Function to Disease; Granger, D.N., Granger, J., Morgan \& Claypool Life Sciences, Eds.; Morgan \& Clay pool Life Sciences Publishers: San Rafael, CA, USA, 2011; pp. 1-77.

5. Nicholson, J.K.; Holmes, E.; Kinross, J.; Burcelin, R.; Gibson, G.; Jia, W.; Pettersson, S. Host-gut microbiota metabolic interactions. Science 2012, 336, 1262-1267. [CrossRef]

6. Lloyd-Price, J.; Abu-Ali, G.; Huttenhower, C. The healthy human microbiome. Genome Med. $2016,8,51$. [CrossRef] [PubMed]

7. Tap, J.; Mondot, S.; Levenez, F.; Pelletier, E.; Caron, C.; Furet, J.-P.; Ugarte, E.; Muñoz-Tamayo, R.; Paslier, D.L.E.; Nalin, R.; et al. Towards the human intestinal microbiota phylogenetic core. Environ. Microbiol. 2009, 11, 2574-2584. [CrossRef]

8. Suau, A.; Bonnet, R.; Sutren, M.; Godon, J.-J.; Gibson, G.R.; Collins, M.D.; Doré, J. Direct analysis of genes encoding 16S rRNA from complex communities reveals many novel molecular species within the human gut. Appl. Environ. Microbiol. 1999, 65, 4799-4807. [CrossRef]

9. Arumugam, M.; Raes, J.; Pelletier, E.; Le Paslier, D.; Yamada, T.; Mende, D.R.; Fernandes, G.R.; Tap, J.; Bruls, T.; Batto, J.M.; et al. Enterotypes of the human gut microbiome. Nature 2011, 473, 174-180. [CrossRef]

10. Seksik, P.; Rigottier-Gois, L.; Gramet, G.; Sutren, M.; Pochart, P.; Marteau, P.; Jian, R.; Doré, J. Alterations of the dominant faecal bacterial groups in patients with Crohn's disease of the colon. Gut 2003, 52, 237-242. [CrossRef]

11. Claesson, M.J.; Cusack, S.; O'Sullivan, O.; Greene-Diniz, R.; De Weerd, H.; Flannery, E.; Marchesi, J.R.; Falush, D.; Dinan, T.G.; Fitzgerald, G.F.; et al. Composition, variability, and temporal stability of the intestinal microbiota of the elderly. Proc. Natl. Acad. Sci. USA 2011, 108 (Suppl. 1), 4586-4591. [CrossRef]

12. Claesson, M.J.; Jeffery, I.B.; Conde, S.; Power, S.E.; O'Connor, E.M.; Cusack, S.; Harris, H.M.B.; Coakley, M.; Lakshminarayanan, B.; O'Sullivan, O.; et al. Gut microbiota composition correlates with diet and health in the elderly. Nature 2012, 488, 178-184. [CrossRef] [PubMed] 
13. Lewis, B.B.; Buffie, C.G.; Carter, R.A.; Leiner, I.; Toussaint, N.C.; Miller, L.C.; Gobournet, A.; Ling, L.; Pamer, E.G. Loss of microbiota-mediated colonization resistance to Clostridium difficile infection is greater following oral vancomycin as compared with metronidazole. J. Infect. Dis. 2015, 212, 1656-1665. [CrossRef]

14. Scott, K.P.; Antoine, J.-M.; Midtvedt, T.; van Hemert, S. Manipulating the gut microbiota to maintain health and treat disease. Microb. Ecol. Health Dis. 2015, 26, 25877. [CrossRef] [PubMed]

15. Rao, S.C.; Athalye-Jape, G.K.; Deshpande, G.C.; Simmer, K.N.; Patole, S.K. Probiotic supplementation and late-onset sepsis in preterm infants: A meta-analysis. Pediatrics 2016, 137, e20153684. [CrossRef] [PubMed]

16. Bagchi, T. Traditional food \& modern lifestyle: Impact of probiotics. Indian J. Med. Res. 2014, 140, $333-335$.

17. Ciani, M.; Mannazzu, I.; Domizio, P. Microbiota of Fermented Beverages. Fermentation 2018, 4, 78. [CrossRef]

18. Bongaerts, G.P.A.; Severijnen, R.S.V.M. A reassessment of the PROPATRIA study and its implications for probiotic therapy. Nat. Biotechnol. 2016, 34, 55-63. [CrossRef]

19. Sornplang, P.; Piyadeatsoontorn, S. Probiotic isolates from unconventional sources: A review. J. Anim. Sci. Technol. 2016, 58, 26. [CrossRef]

20. Arora, T.; Singh, S.; Sharma, R.K. Probiotics: Interaction with gut microbiome and antiobesity potential. Nutrition 2013, 29, 591-596. [CrossRef]

21. Chen, X.; Yang, G.; Song, J.-H.; Xu, H.; Li, D.; Goldsmith, J.; Zeng, H.; Parsons-Wingerter, P.A.; Reinecker, H.-C.; Kelly, C.P. Probiotic yeast inhibits VEGFR signaling and angiogenesis in intestinal inflammation. PLoS ONE 2013, 8, e64227. [CrossRef]

22. Cleveland Clinic. Probiotics. Available online: https://my.clevelandclinic.org/health/articles/14598-probiotics (accessed on 24 September 2020).

23. Wegh, C.; Geerlings, S.Y.; Knol, J.; Roeselers, G.; Belzer, C. Postbiotics and Their Potential Applications in Early Life Nutrition and Beyond. Int. J. Mol. Sci. 2019, 20, 4673. [CrossRef] [PubMed]

24. Markowiak, P.; Śliżewska, K. Effects of Probiotics, Prebiotics, and Synbiotics on Human Health. Nutrients 2017, 9, 1021. [CrossRef] [PubMed]

25. O'Grady, J.; O'Connor, E.M.; Shanahan, F. Review article: Dietary fibre in the era of microbiome science. Aliment. Pharmacol. Ther. 2019, 49, 506-515. [CrossRef] [PubMed]

26. Giorgetti, G.M.; Brandimarte, G.; Fabiocchi, F.; Ricci, S.; Flamini, P.; Sandri, G.; Trotta, M.C.; Elisei, W.; Penna, A.; Lecca, P.G.; et al. Interactions between innate immunity, microbiota, and probiotics. J. Immunol. Res. 2015, 2015, 501361. [CrossRef]

27. Nataraj, B.H.; Ali, S.A.; Behare, P.V.; Yadav, H. Postbiotics-parabiotics: The new horizons in microbial biotherapy and functional foods. Microb. Cell Fact. 2020, 19, 168. [CrossRef]

28. Szajewska, H.; Skórka, A.; Pieścik-Lech, M. Fermented infant formulas without live bacteria: A systematic review. Eur. J. Pediatr. 2015, 174, 1413-1420. [CrossRef]

29. Vyas, U.; Ranganathan, N. Probiotics, prebiotics, and symbiotics: Gut and beyond. Gastroenterol. Res. Pract. 2012, 2012, 872716. [CrossRef]

30. Thomas, L.V. Probiotics-the journey continues. Int. J. Dairy Technol. 2016, 69, 469-480. [CrossRef]

31. Hutkins, R.W.; Krumbeck, J.A.; Bindels, L.B.; Cani, P.D.; Fahey, G.; Goh, Y.J.; Hamaker, B.; Martens, E.C.; Mills, D.A.; Rastal, R.A.; et al. Prebiotics: Why definitions matter. Curr. Opin. Biotechnol. 2016, 37, 1-7. [CrossRef]

32. Tejero-Sarinena, S.; Barlow, J.; Costabile, A.; Gibson, G.R.; Rowland, I. Antipathogenic activity of probiotics against Salmonella typhimurium and Clostridium difficile in anaerobic batch culture systems: Is it due to synergies in probiotic mixtures or the specificity of single strains? Anaerobe 2013, 24, 60-65. [CrossRef]

33. Tufarelli, V.; Laudadio, V. An overview on the functional food concept: Prospectives and applied researches in probiotics, prebiotics and synbiotics. J. Exp. Biol. Agric. Sci. 2016, 4, 273-278. [CrossRef]

34. García-Ruiz, A.; González de Llano, D.; Esteban-Fernández, A.; Requena, T.; Bartolomé, B.; Moreno-Arribas, M. Assessment of probiotic properties in lactic acid bacteria isolated from wine. Food Microbiol. 2014, 44, 220-225. [CrossRef]

35. Le Roy, C.I.; Wells, P.M.; Si, J.; Raes, J.; Bell, J.T.; Spector, T.D. Red Wine Consumption Associated with Increased Gut Microbiota $\alpha$-diversity in 3 Independent Cohorts. Gastroenterology 2020, 158, 270-272. [CrossRef] [PubMed]

36. Moré, M.I.; Swidsinski, A. Saccharomyces boulardii CNCM I-745 supports regeneration of the intestinal microbiota after diarrheic dysbiosis-A review. Clin. Exp. Gastroenterol. 2015, 8, 237-255. [CrossRef] [PubMed] 
37. Fietto, J.L.; Araújo, R.S.; Valadão, F.N.; Fietto, L.G.; Brandão, R.L.; Neves, M.J.; Gomes, F.C.; Nicoli, J.R.; Castro, I.M. Molecular and physiological comparisons between Saccharomyces cerevisiae and Saccharomyces boulardii. Can. J. Microbiol. 2004, 50, 615-621. [CrossRef] [PubMed]

38. Tasteyre, A.; Barc, M.; Karjalainen, T.; Bourlioux, P.; Collignon, A. Inhibition of in vitro cell adherence of Clostridium difficile by Saccharomyces boulardii. Microb. Pathog. 2002, 32, 219-225. [CrossRef] [PubMed]

39. Zbar, N.S.; Nashi, L.F.; Saleh, S.M. Saccharomyces boulardii as effective probiotic against Shiegella flexneri in mice. Int. J. Mat. Meth. Technol. 2013, 1, 17-21.

40. Tiago, F.C.P.; Martins, F.S.; Souza, E.L.S.; Pimenta, P.F.P.; Araujo, H.R.C.; Castro, I.M.; Brandão, R.L.; Nicoli, J.R. Adhesion to the yeast cell surface as a mechanism for trapping pathogenic bacteria by Saccharomyces probiotics. J. Med. Microbiol. 2012, 61, 1194-1207. [CrossRef]

41. McFarland, L.V. Systematic review, and meta-analysis of Saccharomyces boulardii in adult patients. World J. Gastroenterol. 2010, 16, 2202-2222. [CrossRef]

42. Fleet, G.H. Yeasts in foods and beverages: Impact on product quality and safety. Curr. Opin. Biotechnol. 2007, 18, 170-175. [CrossRef]

43. Llanos, R.; Querol, A.; Peman, J.; Gobernado, M.; Fernandez-Espinar, M.T. Food and probiotic strains from the Saccharomyces cerevisiae species as a possible origin of human systemic infections. Int. J. Food Microbiol. 2006, 110, 286-290. [CrossRef] [PubMed]

44. MacKenzie, D.A.; Defernez, M.; Dunn, W.B.; Brown, M.; Fuller, L.J.; de Herrera, S.R.; Günther, A.; James, S.A.; Eagles, J.; Philo, M.; et al. Relatedness of medically important strains of Saccharomyces cerevisiae as revealed by phylogenetics and metabolomics. Yeast 2008, 25, 501-512. [CrossRef] [PubMed]

45. Sen, S.; Mansell, T.J. Yeasts as probiotics: Mechanisms, outcomes, and future potential. Fungal Genet. Biol. 2020, 137, 103333. [CrossRef] [PubMed]

46. Khatri, I.; Tomar, R.; Ganesan, K.; Prasad, G.S.; Subramanian, S. Complete genome sequence and comparative genomics of the probiotic yeast Saccharomyces boulardii. Sci. Rep. 2017, 7, 371. [CrossRef]

47. Edwards-Ingram, L.; Gitsham, P.; Burton, N.; Warhurst, G.; Clarke, I.; Hoyle, D.; Oliver, S.G.; Stateva, L. Genotypic and physiological characterization of Saccharomyces boulardii, the probiotic strain of Saccharomyces cerevisiae. Appl. Environ. Microbiol. 2007, 73, 2458-2467. [CrossRef]

48. Capece, A.; Romaniello, R.; Pietrafesa, A.; Siesto, G.; Pietrafesa, R.; Zambuto, M.; Romano, P. Use of Saccharomyces cerevisiae var. boulardii in co-fermentations with S. cerevisiae for the production of craft beers with potential healthy value-added. Int. J. Food Microbiol. 2018, 284, 22-30. [CrossRef]

49. Lara-Hidalgo, C.E.; Hernández-Sánchez, H.; Hernández-Rodríguez, C.; Dorantes-Álvarez, L. Yeasts in Fermented Foods and their Probiotic Potential. Austin J. Nutr. Metab. 2017, 4, 1043-1045.

50. Páez-Lerma, J.; Arias-García, A.; Rutiaga-Quiñones, O.; Barrio, E.; Soto-Cruz, N. Yeasts isolated from the alcoholic fermentation of Agave duranguesis during mezcal production. Food Biotechnol. 2014, 27, 342-356. [CrossRef]

51. Agarbati, A.; Canonico, L.; Marini, E.; Zannini, E.; Ciani, M.; Comitini, F. Potential Probiotic Yeasts Sourced from Natural Environmental and Spontaneous Processed Foods. Foods 2020, 9, 287. [CrossRef] [PubMed]

52. Kumura, H.; Tanoue, Y.; Tsukahara, M.; Tanaka, T.; Shimazaki, K. Screening of dairy yeast strains for probiotic applications. J. Dairy Sci. 2004, 87, 4050-4056. [CrossRef]

53. Psani, M.; Kotzekidou, P. Technological characteristics of yeast strains and their potential as starter adjuncts in Greek-style black olive fermentation. World J. Microbiol. Biotechnol. 2006, 22, 1329-1336. [CrossRef]

54. Maccaferri, S.; Klinder, A.; Brigidi, P.; Cavina, P.; Costabile, A. Potential probiotic Kluyveromyces marxianus B0399 modulates the immune response in Caco-2 cells and peripheral blood mononuclear cells and impacts the human gut microbiota in an in vitro colonic model system. Appl. Environ. Microbiol. 2012, 78, 956-964. [CrossRef] [PubMed]

55. Ochangco, H.S.; Gamero, A.; Smith, I.M.; Christensen, J.E.; Jespersen, L.; Arneborg, N. In vitro investigation of Debaryomyces hansenii strains for potential probiotic properties. World J. Microbiol. Biotechnol. 2016, 32, 141. [CrossRef] [PubMed]

56. Smith, I.M.; Baker, A.; Arneborg, N.; Jespersen, L. Non-Saccharomyces yeasts protect against epithelial cell barrier disruption induced by Salmonella enterica subsp. enterica serovar Typhimurium. Lett. Appl. Microbiol. 2015, 61, 491-497. [CrossRef] [PubMed]

57. Saber, A.; Alipour, B.; Faghfoori, Z.; Yari, K.A. Cellular and molecular effects of yeast probiotics on cancer. Crit. Rev. Microbiol. 2017, 43, 96-115. [CrossRef] 
58. EFSA Panel on Biological Hazards (BIOHAZ); Ricci, A.; Allende, A.; Bolton, D.; Chemaly, M.; Davies, R.; Girones, R.; Koutsoumanis, K.; Herman, L.; Lindqvist, R.; et al. Update of the list of QPS-recommended biological agents intentionally added to food or feed as notified to EFSA 5: Suitability of taxonomic units notified to EFSA until September 2016. EFSA J. 2017, 15, e04663.

59. Vilela, A. The Importance of Yeasts on Fermentation Quality and Human Health-Promoting Compounds. Fermentation 2019, 5, 46. [CrossRef]

60. Teoh, A.L.; Heard, G.; Cox, J. Yeast ecology of Kombucha fermentation. Int. J. Food Microbiol. 2004, 95, 119-126. [CrossRef]

61. Dutta, D.; Gachhui, R. Novel nitrogen fixing Acetobacter nitrogenifigens sp. nov., isolated from Kombucha tea. Int. J. Syst. Evol. Microbiol. 2006, 56, 1899-1903. [CrossRef]

62. Dutta, D.; Gachhui, R. Nitrogen-fixing, and cellulose-producing Gluconacetobacter kombuchae sp. nov., isolated from Kombucha tea. Int. J. Syst. Evol. Microbiol. 2007, 57, 353-357. [CrossRef]

63. Pidoux, M.; Brillouet, J.; Quemener, B. Characterization of the polysaccharides from a Lactobacillus brevis and from sugary kefir grains. Biotechnol. Lett. 1988, 10, 415-420. [CrossRef]

64. Martínez-Torres, A.; Gutiérrez-Ambrocio, S.; Heredia-del-Orbe, P.; Villa-Tanaca, L.; Hernández-Rodríguez, C. Inferring the role of microorganisms in water kefir fermentations. Int. J. Food Sci. Technol. 2017, 52, 559-571. [CrossRef]

65. Gotcheva, V.; Pandiella, S.S.; Angelov, A.; Roshkova, Z.; Webb, C. Monitoring the fermentation of the traditional Bulgarian beverage boza. Int. J. Food Sci. Technol. 2001, 36, 129-134. [CrossRef]

66. Baschali, A.; Tsakalidou, E.; Kyriacou, A.; Karavasiloglou, N.; Matalas, A. Traditional low-alcoholic and non-alcoholic fermented beverages consumed in European countries: A neglected food group. Nutr. Res. Rev. 2017, 30, 1-24. [CrossRef]

67. Dlusskaya, E.; Jänsch, A.; Schwab, C.; Gänzle, M. Microbialand chemical analysis of a kvass fermentation. Eur. Food Res. Technol. 2008, 227, 261-266. [CrossRef]

68. Inês, A.F.H. Abordagem Polifásica na Caracterização e Selecção de Bactérias do Ácido Láctico de Vinhos da Região Demarcada do Douro. Ph.D. Thesis, Universidade de Trás-os-Montes e Alto Douro, Vila Real, Portugal, 2007; 198p.

69. Inês, A.; Tenreiro, T.; Tenreiro, R. Mendes-Faia A: Review: The lactic acid bacteria of wine-Part I. Ciência e Técnica Vitivinícola 2008, 23, 81-96.

70. Inês, A.; Tenreiro, T.; Tenreiro, R. Mendes-Faia A: The lactic acid bacteria of wine- Part II. Ciência e Técnica Vitivinícola 2009, 24, 1-23.

71. Nagashima, A.I.; Pansiera, P.E.; Baracat, M.M.; Gómez, R.J.H.C. Development of effervescent products, in powder and tablet form, supplemented with probiotics Lactobacillus acidophilus and Saccharomyces boulardii. Food Sci. Technol. 2013, 33, 605-611. [CrossRef]

72. Sreeja, V.; Prajapati, J.B. Probiotic formulations: Application and status as pharmaceuticals-A review. Probiotics Antimicrob. Proteins 2013, 5, 81-91. [CrossRef]

73. Prebiotech Healthcare. Available online: http://prebiotech.com (accessed on 10 November 2020).

74. Laboratoires Nutrisanté. Available online: https://www.nutrisante.fr/en/home/ (accessed on 10 November 2020).

75. ZUMUB. Available online: https://www.zumub.com (accessed on 10 November 2020).

76. Eladiet. Available online: https://www.eladiet.com (accessed on 10 November 2020).

77. Foligné, B.; Dewulf, J.; Breton, J.; Claisse, O.; Lonvaud-Funel, A.; Pot, B. Probiotic properties of non-conventional lactic acid bacteria: Immunomodulation by Oenococcus oeni. Int. J. Food Microbiol. 2010, 140, 136-145. [CrossRef]

78. Krishnamoorthy, M.; Arjun, P. Probiotic and antimicrobial activity of bacteria from fermented toddy of Cocus nucifera. J. Acad. Ind. Res. 2012, 1, 127-131.

79. Vasudha, S.; Mishra, H.N. Non-dairy probiotic beverages. Int. Food Res. J. 2013, 20, 7-15.

80. Kivanc, M.; Yilmaz, M.; Cakir, E. Isolation and identification of lactic acid bacteria from Boza, and their microbial activity against several reporter strains. Turk. J. Biol. 2011, 35, 313-324.

81. Oluwajoba, S.O.; Akinyosoye, F.A.; Oyetayo, V.O. In vitro screening and selection of probiotic lactic acid bacteria isolated from spontaneously fermenting Kunu-Zaki. Adv. Microbiol. 2013, 3, 309-316. [CrossRef] 
82. Amoutzopoulos, B.; Löker, G.B.; Samur, G.; Çevikkalp, S.A.; Yaman, M.; Timur, K.; Pelvan, E. Effects of a traditional fermented grape-based drink "hardaliye" on antioxidant status of healthy adults: A randomized controlled clinical trial. J. Sci. Food Agric. 2013, 93, 3604-3610. [CrossRef]

83. Arici, M.; Coskun, F. Hardaliye: Fermented grape juice as a traditional Turkish beverage. Food Microbiol. 2001, 18, 417-421. [CrossRef]

84. Laureys, D.; De Vuyst, L. Microbial species diversity, community dynamics, and metabolite kinetics of water kefir fermentation. Appl. Environ. Microbiol. 2014, 80, 2564-2572. [CrossRef]

85. Verce, M.; De Vuyst, L.; Weckx, S. Shotgun metagenomics of a water kefir fermentation ecosystem reveals a novel Oenococcus species. Front. Microbiol. 2019, 10, 479. [CrossRef]

86. Park, Y.U.; Kim, M.D.; Jung, D.H.; Seo, D.H.; Jung, J.H.; Park, J.W.; Hong, S.Y.; Cho, J.Y.; Park, S.Y.; Shin, W.C.; et al. Probiotic properties of lactic acid bacteria isolated from Korean rice wine makgeolli. Food Sci. Biotechnol. 2015, 24, 1761-1766. [CrossRef]

87. Fossi, B.T.; Goghomu, S.; Tongwa, M.; Ndjouenkeu, R.; Cho Ngwa, F. Screening for bacteriocins producing probiotic bacteria from fermented sap of palm trees (Elaeis guineesis and Raffia sudanica): Production and partial characterization of bacteriocins. J. Appl. Biotechnol. Bioeng. 2017, 2, 1-8. [CrossRef]

88. Astudillo-Melgar, F.; Ochoa-Leyva, A.; Utrilla, J.; Huerta-Beristain, G. Bacterial diversity and population dynamics during the fermentation of palm wine from Guerrero Mexico. Front. Microbiol. 2019, 10, 531. [CrossRef] [PubMed]

89. Kouamé, H.K.; Aké, M.D.F.; Assohoun, N.M.C.; Djè, M.K.; Djéni, N.T. Dynamics and species diversity of lactic acid bacteria involved in the spontaneous fermentation of various palm tree saps during palm wine tapping in Côte d'Ivoire. World J. Microbiol. Biotechnol. 2020, 36, 64. [CrossRef] [PubMed]

90. Inês, A.; Falco, V. Lactic Acid Bacteria Contribution to Wine Quality and Safety. In Generation of Aromas and Flavours; Vilela, A., Ed.; IntechOpen: London, UK, 2018; pp. 53-71. [CrossRef]

91. Su, J.; Wang, T.; Li, Y.Y.; Li, J.; Zhang, Y.; Wang, Y.; Wang, H.; Li, H. Antioxidant properties of wine lactic acid bacteria: Oenococcus oeni. Appl. Microbiol. Biotechnol. 2015, 99, 5189-5202. [CrossRef] [PubMed]

92. Gibson, G.R.; Roberfroid, M.B. Dietary modulation of the human colonic microbiota: Introducing the concept of prebiotics. J. Nutr. 1995, 125, 1401-1412. [CrossRef] [PubMed]

93. Gibson, G.R.; Probert, H.M.; Loo, J.V.; Rastall, R.A.; Roberfroid, M.B. Dietary modulation of the human colonic microbiota: Updating the concept of prebiotics. Nutr. Res. Rev. 2004, 17, 259-275. [CrossRef] [PubMed]

94. Gibson, G.R.; Scott, K.P.; Rastall, R.A.; Tuohy, K.M.; Hotchkiss, A.; Dubert-Ferrandon, A.; Gareau, M.; Murphy, E.F.; Saulnier, D.; Loh, G.; et al. Dietary prebiotics: Current status and new definition. Food Sci. Technol. Bull. Funct. Foods 2010, 7, 1-19. [CrossRef]

95. Cloetens, L.; Ulmius, M.; Johansson-Persson, A.; Akesson, B.; Onning, G. Role of dietary beta-glucans in the prevention of the metabolic syndrome. Nutr. Rev. 2012, 70, 444-458. [CrossRef]

96. Fuentes-Zaragoza, E.; Sánchez-Zapata, E.; Sendra, E.; Sayas, E.; Navarro, C.; Fernández-López, J.; Pérez-Alvarez, J.A. Resistant starch as prebiotic: A review. Starch-Stärke 2011, 63, 406-415. [CrossRef]

97. Tomomatsu, H. Health Effects of Oligosaccharides. Food Technol. 1994, 10, 61-65.

98. Mussatto, S.I.; Mancilha, I.M. Nondigestible oligosaccharides: A review. Carbohydr. Polym. 2007, 68, 587-597. [CrossRef]

99. Van Loo, J.; Coussement, P.; de Leenheer, L.; Hoebregs, H.; Smits, G. On the presence of inulin and oligofructose as natural ingredients in the western diet. Crit. Rev. Food Sci. Nutr. 1995, 35, 525-552. [CrossRef] [PubMed]

100. Shigwedha, N.; Hiwilepo-Van Hal, P.; Jia, L.; Sichel, L.; Zhang, S. Prebiotics: Metabolism and Symbiotic Synergy with Probiotics in Promoting Health. In Probiotics and Prebiotics in Human Nutrition and Health; Rao, V., Rao, L.G., Eds.; IntechOpen: London, UK, 2016. [CrossRef]

101. Ziemer, C.J.; Gibson, G.R. An overview of probiotics, prebiotics and synbiotics in the functional food concept: Perspectives and future strategies. Int. Dairy J. 1998, 8, 473-479. [CrossRef]

102. Sangeetha, P.T.; Ramesh, M.N.; Prapulla, S.G. Recent trends in the microbial production, analysis and application of FOS. Trends Food Sci. Technol. 2005, 16, 442-457. [CrossRef]

103. Voragen, A.G.J. Technological aspects of functional food-related carbohydrates. Trends Food Sci. Technol. 1998, 9, 328-335. [CrossRef]

104. Niness, K.R. Inulin and Oligofructose: What Are They? J. Nutr. 1999, 129, 1402S-1406S. [CrossRef] 
105. Carpita, N.C.; Kanabus, J.; Housley, T.L. Linkage Structure of Fructans and Fructan Oligomers from Triticum aestivum and Festuca arundinacea Leaves. J. Plant Physiol. 1989, 134, 162-168. [CrossRef]

106. Lazaridou, A.; Biliaderis, C.G. Molecular aspects of cereal beta-glucan functionality: Physical properties, technological applications, and physiological effects. J. Cereal Sci. 2007, 46, 101-118. [CrossRef]

107. Ahmad, A.; Munir, B.; Abrar, M.; Bashir, S.; Adnan, M.; Tabassum, T. Perspective of $\beta$-Glucan as functional ingredient for food industry. J. Nutr. Food Sci. 2012, 2, 133. [CrossRef]

108. Aida, F.M.N.A.; Shuhaimi, M.; Yazid, M.; Maaruf, A.G. Mushroom as a potential source of prebiotics: A review. Trends Food Sci. Technol. 2009, 20, 567-575. [CrossRef]

109. Lam, K.L.; Chi-Keung, C.P. Non-digestible long chain beta-glucans as novel prebiotics. Bioact. Carbohydr. Diet. Fibre 2013, 2, 45-64. [CrossRef]

110. Inglett, G.E.; Carriere, C.J.; Maneepun, S.; Tungtrakul, P. A soluble fibre gel produced from rice bran and barley flour as a fat replacer in Asian foods. Int. J. Food Sci. Technol. 2004, 39, 1-10. [CrossRef]

111. Lina, B.A.R.; Jonker, D.; Kozianowsky, G. Isomaltulose (Palatinose): A review of biological and toxicological studies. Food Chem. Toxicol. 2002, 40, 1375-1381. [CrossRef]

112. Takazoe, I. New trends on sweeteners in Japan. Int. Dent. J. 1985, 35, 58-65.

113. Aachary, A.A.; Prapulla, S.G. Xylooligosaccharides (XOS) as an Emerging Prebiotic: Microbial Synthesis, Utilization, Structural Characterization, Bioactive Properties, and Applications. Compr. Rev. Food Sci. Food Saf. 2011, 10, 2-16. [CrossRef]

114. Vazquez, M.J.; Alonso, J.L.; Domınguez, H.; Parajo, J.C. Xylooligosaccharides: Manufacture and applications. Trends Food Sci. Technol. 2000, 11, 387-393. [CrossRef]

115. Tsao, R. Chemistry and biochemistry of dietary polyphenols. Nutrients 2010, 2, 1231-1246. [CrossRef]

116. Hervert-Hernández, D.; Goñi, I. Dietary Polyphenols and Human Gut Microbiota: A Review. Eur. J. Nutr. 2011, 54, 325-341. [CrossRef]

117. Cardona, F.; Andrés-Lacueva, C.; Tulipani, S.; Tinahones Francisco, J.; Queipo-Ortuño, M.I. Benefits of polyphenols on gut microbiota and implications in human health. J. Nutr. Biochem. 2013, 24, 1415-1422. [CrossRef]

118. Duda-Chodak, A.; Tarko, T.; Satora, P.; Sroka, P. Interaction of dietary compounds, especially polyphenols, with the intestinal microbiota: A review. Eur. J. Nutr. 2015, 54, 25-341. [CrossRef]

119. Kawabata, K.; Yoshioka, Y.; Terao, J. Role of Intestinal Microbiota in the Bioavailability and Physiological Functions of Dietary Polyphenols. Molecules 2019, 24, 370. [CrossRef]

120. Parkar, S.G.; Stevenson, D.E.; Skinner, M.A. The potential influence of fruit polyphenols on colonic microflora and human gut health. Int. J. Food Microbiol. 2008, 124, 295-298. [CrossRef] [PubMed] 
121. Queipo-Ortuño, M.I.; Boto-Ordóñez, M.; Murri, M.; Gómez-Zumaquero, J.M.; Clemente-Postigo, M.; Estruch, R.; Cardona Diaz, F.; Andrés-Lacueva, C.; Tinahones, F.J. Influence of red wine polyphenols and ethanol on the gut microbiota ecology and biochemical biomarkers. Am. J. Clin. Nutr. 2012, 95, 1323-1334. [CrossRef] [PubMed]

122. Cueva, C.; Sánchez-Patán, F.; Monagas, M.; Watson, G.; Gibson, G.R.; Martín-Álvarez, P.J.; Bartolomé, B.; Moreno-Arribas, M.V. In vitro fermentation of grape seed flavan-3-ol fractions by human faecal microbiota: Changes in microbial groups and phenolic metabolites. FEMS Microb. Ecol. 2013, 83, 792-805. [CrossRef] [PubMed]

123. Requena, T.; Monagas, M.; Pozo-Bayón, M.A.; Martín-Álvarez, P.J.; Bartolomé, B.; del Campo, R.; Ávila, M.; Martínez-Cuesta, M.C.; Peláez, C.; Moreno-Arribas, M.V. Perspectives of the potential implications of wine polyphenols on human oral and gut microbiota. Trends Food Sci. Technol. 2010, 21, 332-344. [CrossRef]

124. Rodríguez-Vaquero, M.J.; Alberto, M.R.; Manca de Nadra, M.C. Antibacterial effect of phenolic compounds from different wines. Food Control 2007, 18, 93-101. [CrossRef]

125. Cueva, C.; Gil-Sánchez, I.; Ayuda-Durán, B.; González-Manzano, S.; González-Paramás, A.M.; Santos-Buelga, C.; Bartolomé, B.; Moreno-Arribas, M.A. An integrated view of the effects of wine polyphenols and their relevant metabolites on gut and host health. Molecules 2017, 22, 99. [CrossRef]

126. Prado, F.C.; Parada, J.L.; Pandey, A.; Soccol, C.R. Trends in non-dairy probiotic beverages. Food Res. Int. 2008, 41, 111-123. [CrossRef]

127. Xu, J.; Inglett, G.E.; Liu, S.X.; Boddu, V.M. Micro-heterogeneity and micro-rheological properties of high-viscosity barley $\beta$-glucan solutions studied by diffusing wave spectroscopy (DWS). Food Biophys. 2016, 11, 339-344. [CrossRef]

128. Goncerzewicz, A.; Misiewicz, A.; Owczarek, L.; Jasińska, U.; Skapska, S. The effect of a newly developed oat-banana fermented beverage with a beta-glucan additive on ldhL gene expression in Streptococcus thermophilus TKM3 KKP 2030p. Curr. Microbiol. 2016, 73, 773-780. [CrossRef]

129. Rathore, S.; Salmeron, I.; Pandiella, S.S. Production of potentially probiotic beverages using single and mixed cereal substrates fermented with lactic acid bacteria cultures. Food Microbiol. 2012, 30, 239-244. [CrossRef]

130. Mugula, J.K.; Nnko, S.A.M.; Narvhus, J.A.; Sørhaug, T. Microbiological and fermentation characteristics of togwa, a Tanzanian fermented food. Int. J. Food Microbiol. 2003, 80, 187-199. [CrossRef]

131. Blandino, A.; Al-Aseeri, M.E.; Pandiella, S.S.; Cantero, D.; Webb, C. Cereal-based fermented foods and beverages. Food Res. Int. 2003, 36, 527-543. [CrossRef]

132. Soro-Yao, A.A.; Brou, K.; Amani, G.; Thonart, P.; Djè, K.M. The Use of Lactic Acid Bacteria Starter Cultures during the Processing of Fermented Cereal-based Foods in West Africa: A Review. Trop. Life Sci. Res. 2014, 25, 81-100. [PubMed]

133. Uzogara, S.G.; Agu, L.N.; Uzogara, E.O. A review of traditional fermented foods, condiments, and beverages in Nigeria: Their benefits and possible problems. Ecol. Food Nutr. 1990, 24, 267-288. [CrossRef]

134. Nout, M.J.R. Rich nutrition from the poorest-Cereal fermentations in Africa and Asia. Food Microbiol. 2009, 26, 685-692. [CrossRef] [PubMed]

135. Phiri, S.; Schoustra, S.E.; van den Heuvel, J.; Smid, E.J.; Shindano, J.; Linnemann, A. Fermented cereal-based Munkoyo beverage: Processing practices, microbial diversity and aroma compounds. PLoS ONE 2019, 14, e0223501. [CrossRef] [PubMed]

136. Odunfa, S.A.; Adeyele, S. Microbiological Changes during the Traditional Production of ogi-baba, a West African Fermented Sorghum Gruel. J. Cereal Sci. 1985, 3, 173-180. [CrossRef]

137. Novellie, L.; De Schaepdrijver, P. Modern developments in traditional African beers. Prog. Ind. Microbiol. 1986, 23, 73-157.

138. Lamsal, B.P.; Faubion, J.M. The beneficial use of cereal components in probiotic foods. Food Rev. Int. 2009, 25, 103-114. [CrossRef]

139. Jovanovic-Malinovska, R.; Kuzmanova, S.; Winkelhausen, E. Oligosaccharide profile in fruits and vegetables as sources of prebiotics and functional foods. Int. J. Food Prop. 2014, 17, 949-965. [CrossRef]

140. Camargo Prado, F.; De Dea Lindner, J.; Inaba, J.; Thomaz-Soccol, V.; Kaur Brar, S.; Soccol, C.R. Development and evaluation of a fermented coconut water beverage with potential health benefits. J. Funct. Foods 2015, 12, 489-497. [CrossRef]

141. Kandylis, P.; Pissaridi, K.; Bekatorou, A.; Kanellaki, M.; Koutinas, A.A. Dairy and non-dairy probiotic beverages. Curr. Opin. Food Sci. 2016, 7, 58-63. [CrossRef] 
142. Battcock, M. Fermented Fruits and Vegetables: A Global Perspective; FAO Agricultural Services Bulletin No. 134; Food and Agriculture Organization of the United Nations (FAO): Rome, Italy, 1998.

143. Lappe-Oliveras, P.; Moreno-Terrazas, R.; Arrizón-Gaviño, J.; Herrera-Suárez, T.; García-Mendoza, A.; Gschaedler-Mathis, A. Yeasts associated with the production of Mexican alcoholic non-distilled and distilled Agave beverages. FEMS Yeast Res. 2008, 8, 1037-1052. [CrossRef] [PubMed]

144. Santiago-Urbina, J.A.; Arias-García, J.A.; Ruiz-Terán, F. Yeast species associated with spontaneous fermentation of taberna, a traditional palm wine from the southeast of Mexico. Ann. Microbiol. 2015, 65, 287-296. [CrossRef]

145. Santiago-Urbina, J.A.; Verdugo-Valdez, A.G.; Ruíz-Terán, F. Physicochemical and microbiological changes during tapping of palm sap to produce an alcoholic beverage called "Taberna", which is produced in the south east of Mexico. Food Control 2013, 33, 58-62. [CrossRef]

146. De la Fuente-Salcido, N.M.; Castañeda-Ramírez, J.C.; García-Almendárez, B.E.; Bideshi, D.K.; Salcedo-Hernández, R.; Barboza-Corona, J.E. Isolation and characterization of bacteriocinogenic lactic bacteria from M-tuba and Tepache, two traditional fermented beverages in México. Food Sci. Nutr. 2015, 3, 434-442. [CrossRef]

Publisher's Note: MDPI stays neutral with regard to jurisdictional claims in published maps and institutional affiliations.

(C) 2020 by the authors. Licensee MDPI, Basel, Switzerland. This article is an open access article distributed under the terms and conditions of the Creative Commons Attribution (CC BY) license (http://creativecommons.org/licenses/by/4.0/). 